\title{
Edward Louis Keenan, 1935-2015
}

Through many types of work in a variety of settings, Edward L. Keenan transformed the field of early modern Russian history. Keenan's scholarly publications, though very important, only tell part of the story, since many of his most important contributions came through the influence he had on a whole generation of historians of Muscovite Russia and through his building the infrastructure of our field.

Born in a small town in western New York State, Keenan completed both his undergraduate and graduate degrees at Harvard University, where he acquired an exceptionally powerful toolbox of skills, including training in structuralism from Roman Jakobson that Ned turned into a cultural-anthropological approach to understanding the "grammar" of Muscovite political life and culture. From his chief mentor, Omeljan Pritsak, he learned to place East Slavic history firmly in the context of the steppe and its languages. Most impressive, however, were Ned's linguistic skills. His ability in spoken Russian was legendary, but he had a highly developed knowledge of the various historical layers and subcultures of Russian and its neighboring languages, including not only Slavic languages but also Uzbek, Chagatai (medieval Uzbek), and Turkmen. Above all, Ned was a lover of language.

Keenan was a tireless builder of institutions that make our work possible. He served Harvard in an astonishing array of positions, in each of which he made significant, often transformative, contributions. He served as director of the Russian Research Center, the Center for Middle Eastern Studies, and the Dumbarton Oaks Research Library and Collection; dean of the Graduate School of Arts and Sciences; chair of the History Department; and an active participant and board member of the Ukrainian Research Institute.

Nationally, he was president of the American Association for the Advancement of Slavic Studies (AAASS, now ASEEES) and a major force behind the founding and running of the National Council for Soviet and Eastern European Research. As chair of the latter organization, he worked to fund the creation of infrastructure for the scanning and dissemination of archival materials and books in both the Soviet Union and the United States. He also helped to found the Bibliography, Information Retrieval, and Documentation (BIRD) Subcommittee of the Social Science Research Council, a group of Slavic librarians from around the country responsible for the ABSEES bibliography.

Keenan's scholarship was concentrated at the opposite ends of the historian's work process: the intensive study of sources and the revision of some of the major accepted narratives of Russian history, both for the Muscovite period and beyond it. His earliest work, based on his dissertation, was on the relationship between the Muscovite state and the surrounding political entities on the western steppe. Using a methodology that would become a hallmark, he de-emphasized the importance of ecclesiastic, literary texts, which stressed the gulf between Christian Muscovy and Muslim Tatar states, and relied instead on documentary evidence, particularly diplomatic sources. This selection inclined him to see Muscovy as one of several players struggling for dominance on the steppe after the fall of the Qipchaq Khanate at the end of the fourteenth century.

His generally skeptical approach to some of the foundational sources of Muscovite history led him to question the traditional attributions of many of these texts, most notably the Correspondence previously attributed to Ivan the IV (the Terrible) and Prince A. M. Kurbskii, which, Keenan argued, was a seventeenth-century forgery. He also 
proposed that the most famous Rus' medieval epic, The Lay of Igor's Campaign, was in fact written by an eminent Czech philologist, Josef Dobrovský, at the end of the eighteenth century. These reattributions inevitably occasioned major scholarly debates; few accept Keenan's opinion on the Lay, while opinion is still sharply divided on the Kurbskii corpus. But his relentless questioning of the sources has had the salutary effect of making us all more critical of traditional dating and attributions, removing texts like the Correspondence from the center of historians' attention (where they were often read to support an imagined conflict between the tsar and his elite) and turning our focus to a wider variety of sources, particularly documentary ones.

This intense scrutiny of the source base led Keenan to construct a new narrative, not only of Muscovite history, but of all Russian history. The most well-known expression of this new view was his 1986 essay "Muscovite Political Folkways" (Russian Review 45, no. 2), but the most fully developed version was contained in his unpublished Harvard lectures. The key idea is that the much-vaunted limitless power of the tsar was an illusion created by the court to conceal a collaborative structure in which the ruler served as a center of gravity keeping the potentially disastrous competition of boyar clans in check, as the nucleus of an atom keeps the protons in balance. Thus he imagined not the usual pyramidal structure of authority, with power flowing exclusively down from the top, but a circular structure, with the ruler at the center and the boyar clans surrounding, each with alliances stretching far out into the countryside. The same cultural habits of risk-averseness and communal decision making that characterized the peasant village also held for the court, but the village had little direct influence on government policy, which remained largely the monopoly of the court. This view of the court has now become generally accepted, especially by American historians of Muscovy, and has been applied to subsequent eras of Russian history as well.

But perhaps Ned's greatest influence on the field was felt through his students. He not only taught an outstanding group of his own graduate students but he also welcomed to Cambridge a cohort from many other universities, admitting them to his seminars and undergraduate lectures and often arranging employment and even housing for them at Harvard. Taken together, these students have had an immense influence on our understanding of Muscovite history, often basing their dissertations on one or more of Keenan's ideas and then doing the archival and other research to fully develop (and sometimes alter) his original thought. For Ned never imposed his ideas on anyone; he infected his students with his enthusiasm and his desire to examine sources meticulously, but was always glad to let young scholars come to their own conclusions.

At the heart of all of this work lay Ned's extraordinary personality. A master of rhetoric in many languages, he was a magnetic and persuasive storyteller, a crucial talent in a discipline that is at base the telling of compelling (and substantiated) stories about our past. Listening to his lectures was like watching a jazz musician improvising on a standard. He dazzled and persuaded us with his language, especially his metaphors connecting remote periods with the present, as when he famously compared Rus' princes to the Mafia. But his intellectual brilliance was matched by his devotion as a teacher and friend: he tirelessly read drafts and wrote recommendations for his students, both official and unofficial, long after their departure from Cambridge. Those of us lucky enough to have studied with him all hold in our memories his eloquence, his ideas, and his inspiring example of an historian's life well lived.

Daniel Rowland

University of Kentucky

May 2015 